\title{
IgE Sensitization to Lupine in Bakers - Cross-Reactivity or Co-Sensitization to Wheat Flour?
}

\author{
Vera van Kampen ${ }^{a} \quad$ Ingrid Sander $^{\mathrm{a}}$ Santiago Quirce ${ }^{\mathrm{b}}$ Thomas Brüning ${ }^{\mathrm{a}}$ \\ Rolf Merget $^{a}$ Monika Raulf ${ }^{a}$ \\ a Institute for Prevention and Occupational Medicine, German Social Accident Insurance, Ruhr University Bochum, \\ Bochum, Germany; ${ }^{b}$ Department of Allergy, Hospital La Paz Institute for Health Research and CIBER of Respiratory \\ Diseases, Madrid, Spain
}

\section{Key Words}

Asthma $\cdot$ Bakers $\cdot$ Cross-reactivity $\cdot$ Lupine $\cdot$ Occupational allergy $\cdot$ Sensitization $\cdot$ Wheat flour

\begin{abstract}
Background: Food allergy to lupine has frequently been reported in patients allergic to peanut or soy, and cross-reactivity between these legumes is known. Moreover, respiratory allergy to lupine has been described after inhalation, mostly at workplaces. Our aim was to study the frequency of lupine sensitization in European bakers with suspected bakers' allergy. Furthermore, associations between sensitizations to lupine and other plant allergens were investigated. Methods: One hundred and sixteen bakers with work-related allergic symptoms but without known food allergies were examined. Specific $\lg E$ (slgE) antibodies to wheat flour, rye flour, lupine, peanut, soy and the recombinant single birch protein $\mathrm{rBet} v 1$ were quantified. Selected sera were tested for cross-reactivity using ImmunoCAP inhibition and ISAC microarrays. Results: Whereas $67 \%$ of bakers were sensitized to wheat and/or rye flour, 35\% showed slgE to peanut and $33 \%$ to lupine. All lupine-positive bakers also had slgE to either wheat flour (89\%) and/or peanut (92\%), and lupine slgE correlated significantly with slgE to peanut, soy, wheat and
\end{abstract}

rye flour. Used as an inhibitor, wheat flour inhibited IgE binding to lupine in 4 out of 8 sera, indicating cross-reactivity. In microarrays, these sera showed IgE binding to lipid transfer proteins, profilins and/or cross-reactive carbohydrate determinants. Further inhibition experiments suggest that these single allergens are involved in cross-reactivity. Conclusion: One third of 116 symptomatic bakers showed slgE to lupine. At least some of these sensitizations were based on crossreactivity between lupine and wheat flour. However, the considerable sensitization rate could also be a sign that the use of lupine flour in bakeries may be of occupational relevance.

๑ 2015 S. Karger AG, Basel

\section{Introduction}

Lupines, like peanuts, soy, peas, lentils and beans are legumes and belong to the Fabaceae family. The use of lupine in baked goods and pasta has recently increased in several European countries due to its high protein and low fat content, in addition to the absence of gluten [1].

However, legumes, in particular peanuts and, to a lesser extent, soy beans, are well-known food allergens [2, 3], and allergy after ingestion of lupine has also been report-

\section{KARGER 125}

(c) 2015 S. Karger AG, Base

1018-2438/15/1661-0063\$39.50/0

E-Mail karger@karger.com

www.karger.com/iaa
Correspondence to: Dr. Vera van Kampen

Institute for Prevention and Occupational Medicine, German Social Accident Insurance Ruhr University Bochum, Bürkle-de-la-Camp-Platz 1

DE-44789 Bochum (Germany)

E-Mail kampen@ipa-dguv.de 
ed [4]. IgE cross-reactivities between lupine, peanut and other legumes have been documented $[1,5]$ and are mainly based on the homology of their storage proteins (conglutins) $[6,7]$. The birch protein Bet $\mathrm{v} 1$ is a homologue of a pathogenesis-related (PR-10) protein of lupine and peanut [8] and of soy bean [9].

According to Moneret-Vautrin et al. [5], the risk of crossed peanut-lupine food allergy is high, which is in contrast to the risk with other legumes. In a study comprising 1,522 patients with suspected food allergy, 25 showed a positive skin prick test (SPT) with lupine. Concomitant positive test reactions to soy, peanut and/or pea in 18 out of 25 patients led the authors to conclude that lupine sensitization appears to represent cross-reactivity to other legumes [10]. Out of 39 unselected peanut-sensitized patients, $82 \%$ had a positive SPT to lupine, and $35 \%$ showed clinical reactivity to lupine during oral challenge tests [11]. In contrast, clinically relevant lupine food allergies that are not associated with peanut or other legumes have rarely been reported [12, 13].

In addition to ingestion, respiratory exposure - mostly at the workplace - also appears to result in allergic reactions to lupine. Parisot et al. [14] reported a case of occupationally induced inhalant allergy to lupine in a 30-year-old environmental technician. After handling lupine flour, the technician suffered from rhinitis, conjunctivitis, and angio-oedema. She showed specific $\operatorname{IgE}$ (sIgE) to lupine in the SPT as well as in the ImmunoCAP test. Furthermore, although sIgE to peanut was detected, she tolerated peanut ingestion without symptoms. In the same year, Crespo et al. [15] investigated 7 patients who were occupationally exposed to lupine and other seedbased flour. Three workers who reported work-related symptoms had a positive SPT with lupine, and 2 of them also reacted in the inhalation challenge as well as in the oral food challenge. Additionally, both showed cross-reactivity to other legumes but had no history of food allergy. In a cross-sectional study on 53 workers exposed to lupine during their work at a food processing company, 11 workers $(21 \%)$ had a positive SPT to lupine. Seven of them (64\%) were symptomatic, and 1 subject showed a positive specific bronchial challenge test with lupine. Cross-reactivity with other legumes could be detected in 4 lupine-sensitized subjects by SPT [16]. Hieta et al. [10] reported a case of occupational allergy caused by lupine in Finland. A 42-year-old baker with work-related rhinitis and dyspnoea had a positive SPT to lupine, whereas his SPT results to other flours used in the bakery and to soy, peanut and pea were negative. The serum concentration of sIgE to lupine was positive $(3.5 \mathrm{kU} / \mathrm{l})$, and therefore it was assumed that some batches of the imported flour used in the bakery contained lupine flour.

Occupational asthma is still a problem in European countries [17]. For many years, the main substances causing allergic occupational obstructive airway diseases in Germany were flour and bakery products [18]. Because lupine flour is increasingly used in bakeries and cases of occupational lupine allergy have been described, we aimed to study the frequency of lupine sensitization in a group of European bakers. In addition, we compared sIgE to lupine with sIgE to peanut, soy, wheat and rye flour and with the major birch allergen Bet $\mathrm{v} 1$ and analysed the possible cross-reactivity between lupine and wheat flour.

\section{Methods}

Study Design and Subjects

This retrospective study includes all bakers who had been previously examined within a European multicentre study for the standardization of the diagnosis for occupational allergy (STADOCA) with the aim to improve the diagnosis of occupational allergy [19]. During the STADOCA project, allergologists collected sera and data from all patients who were examined within the scope of claims for compensation due to occupational asthma in the 15 participating European allergy centres. In total, we obtained data and sera from 116 bakers (37 Polish, 30 German, 18 Italian, 14 Spanish, 10 Austrian and 7 French), all suffering from work-related allergic symptoms. While examinations and SPTs were performed at the allergy centres in the respective countries, sIgE measurements were done centrally at our Institute for Prevention and Occupational Medicine. The study design and the protocol were reviewed and approved by the Ethics Committee of the Ruhr University Bochum in accordance with the Declaration of Helsinki.

\section{Skin Prick Tests}

To identify atopics, an SPT was performed with a panel of common inhalant allergens, including grass pollen, birch pollen and house dust mite (Dermatophagoides pteronyssinus), all from Allergopharma (Reinbek, Germany), in all bakers. Atopy was defined as a mean wheal diameter of $\geq 3 \mathrm{~mm}$ in reaction to at least 1 of these common aeroallergens. Histamine $(10 \mathrm{mg} / \mathrm{ml})$ and saline were used as positive and negative controls, respectively.

\section{sIgE Determination}

sIgE to wheat (f4), rye (f5) and lupine flour (f335) as well as to soy (f14), peanut (f13) and the recombinant single birch protein rBet v 1 (t215) were measured in all sera using ImmunoCAP (ThermoFisher Scientific, Uppsala, Sweden). sIgE values of $\geq 0.35$ $\mathrm{kU} / \mathrm{l}$ were considered positive.

In 8 selected sera samples with moderate-to-high lupine sIgE concentrations, sIgE to the cross-reactive carbohydrate determinant (CCD) horseradish peroxidase (HRP; Ro400) was tested using commercial ImmunoCAP. Wheat lipid transfer protein (LTP; Tri a 14.0201) and wheat profilin (Tri a 12.0102) were coupled to streptavidin ImmunoCAPs as previously described [20] and then used for sIgE measurement. van Kampen/Sander/Quirce/Brüning/ Merget/Raulf 


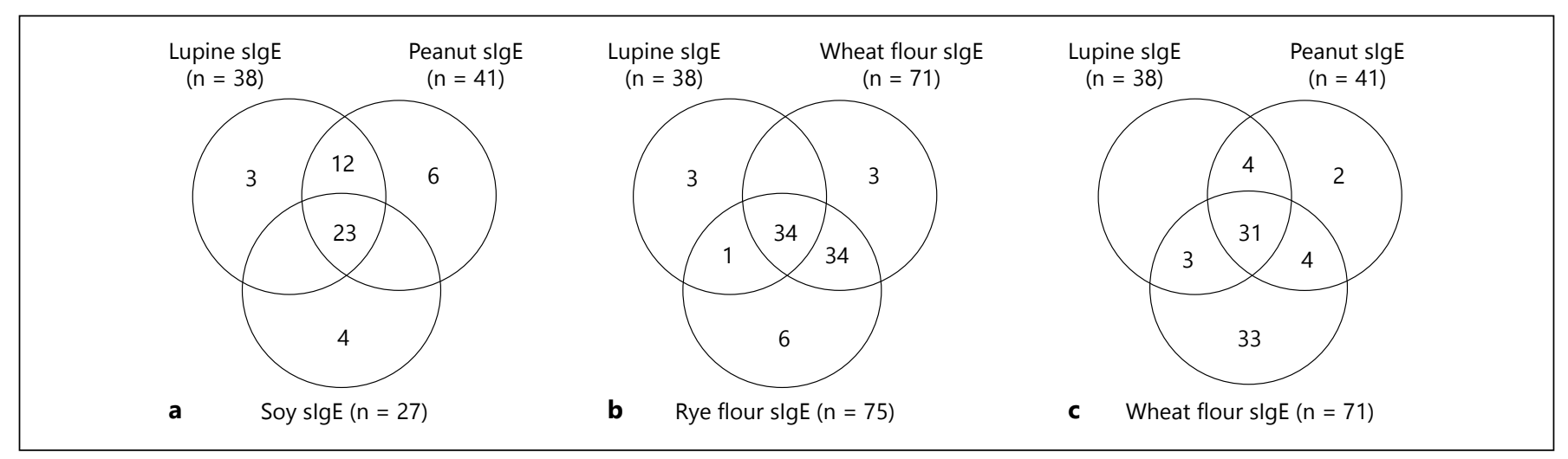

Fig. 1. Venn diagram showing the proportions of $\operatorname{sgE}$ positives to lupine, peanut and soy (a), to lupine, wheat and rye flour (b) and to lupine, peanut and wheat flour (c) out of 116 symptomatic bakers.

For ImmunoCAP inhibition experiments, in the case of higher sIgE concentrations, sera were diluted to sIgE values of $2-3 \mathrm{kU} / \mathrm{l}$. Fifty microlitres of these sera were mixed with $10 \mu \mathrm{l}$ inhibitor solution or phosphate-buffered saline (PBS) before sIgE concentrations were measured using ImmunoCAP. Lupine and wheat flour $(1 \mathrm{mg} / \mathrm{ml} \mathrm{PBS})$ as well as wheat LTP and wheat profilin $(0.1 \mathrm{mg} / \mathrm{ml}$ PBS) and HRP ( $4.5 \mathrm{mg} / \mathrm{ml}$ PBS) were used as inhibitors. In the case of lupine, LTP and profilin, the material used for inhibition was identical to that bound to ImmunoCAPs. Inhibition rates below $20 \%$ were considered negative and those below $40 \%$ low.

The ISAC microarray (ThermoFisher Scientific) enables the measurement of sIgE antibodies to a fixed panel of 112 components from 51 allergen sources in a single step. The results are reported as ISAC standardized units. Following the manufacturer's recommendations, levels $>0.3$ ISAC standardized units/l are regarded as positive. While the ISAC microarray panel contains only 1 CCD (MuXF3, a carbohydrate chain which is found in many plant proteins) and 1 thaumatin-like protein (from kiwi), it contains 10 different PR-10 proteins (from birch, alder, hazel pollen, hazelnut, apple, peach, soy, peanut, kiwi and celery), 8 LTPs [from peanut, hazelnut, walnut, peach, mugwort, olive tree, London plane (Platanus acerifolia) and wheat] and 4 profilins [from birch, latex, dog's mercury (Mercurialis annua) and Timothy grass].

\section{Statistical Analysis}

For correlations, the Spearman rank correlation method was used because data were not normally distributed. A $p$ value of $<0.05$ was considered statistically significant. Data were analysed and visualized by using GraphPad Prism version 5.01 for Windows (GraphPad Software, San Diego, Calif., USA).

\section{Results}

Most of the 116 bakers were male $(81 \%)$ with a mean age of $38.3 \pm 12.0$ years; $31(26.7 \%)$ were current smokers and $20(17.2 \%)$ were ex-smokers. While 56 bakers $(48.3 \%)$ were still working at the time of the study, $60(51.7 \%)$ had left the job due to allergic symptoms. Eighty-nine subjects $(76.7 \%)$ complained of asthma and out of these, 86 also reported rhinitis. Twenty-five bakers (21.6\%) reported rhinitis but no symptoms of asthma. Only 2 bakers reported food allergy, 1 to fish and 1 to kiwi, clam and pineapple.

Seventy-one bakers (61\%) had sIgE to wheat flour (range of positives $0.38-82.6 \mathrm{kU} / \mathrm{l}$, median of positives $2.52 \mathrm{kU} / \mathrm{l}$ ), $75(65 \%)$ to rye flour (range $0.36-91.5 \mathrm{kU} / \mathrm{l}$, median $2.18 \mathrm{kU} / \mathrm{l}$ ), 38 (33\%) to lupine (range 0.36$62.2 \mathrm{kU} / \mathrm{l}$, median $0.87 \mathrm{kU} / \mathrm{l}$ ), 41 (35\%) to peanut (range $0.43-45.8 \mathrm{kU} / \mathrm{l}$, median $0.90 \mathrm{kU} / \mathrm{l}), 27$ (23\%) to soy (range $0.37-17.0 \mathrm{kU} / \mathrm{l}$, median $0.68 \mathrm{kU} / \mathrm{l})$ and $17(15 \%)$ to $\mathrm{rBet}$ $\mathrm{v} 1$ (range from 0.47 to $>100 \mathrm{kU} / \mathrm{l}$, median $5.92 \mathrm{kU} / \mathrm{l}$ ). While only $14 \%$ of the French and $20 \%$ of German bakers were sensitized to lupine, higher percentages were found for Spanish (36\%), Polish (38\%), Italian (39\%) and especially Austrian (50\%) bakers (data not shown). Out of the 38 lupine-sensitized subjects, sIgE to peanut was measured in 35 (92\%) and to soy in 23 (61\%; fig. 1a). Thirtyfour subjects (89\%) were sIgE positive to wheat flour and 35 (92\%) to rye flour (fig. 1b). In total, all lupine-sensitized subjects had sIgE to either wheat flour and/or peanut (fig. 1c). In the 4 lupine-sensitized subjects without sIgE to wheat flour, the lupine sIgE values were very low $(0.36-0.59 \mathrm{kU} / \mathrm{l})$, and 1 subject had sIgE to rye flour $(0.43 \mathrm{kU} / \mathrm{l})$. Eight of the 38 lupine positives $(21 \%)$ had sIgE to rBet $v 1$.

Fifty-four (47\%) out of the total group of 116 bakers and $23(61 \%)$ out of the 38 lupine sIgE positive bakers were atopic according to SPT results with common aeroallergens. Lupine sIgE concentrations correlated significantly with concentrations of sIgE to peanut, soy, wheat and rye flour, with the strongest correlation to peanut 


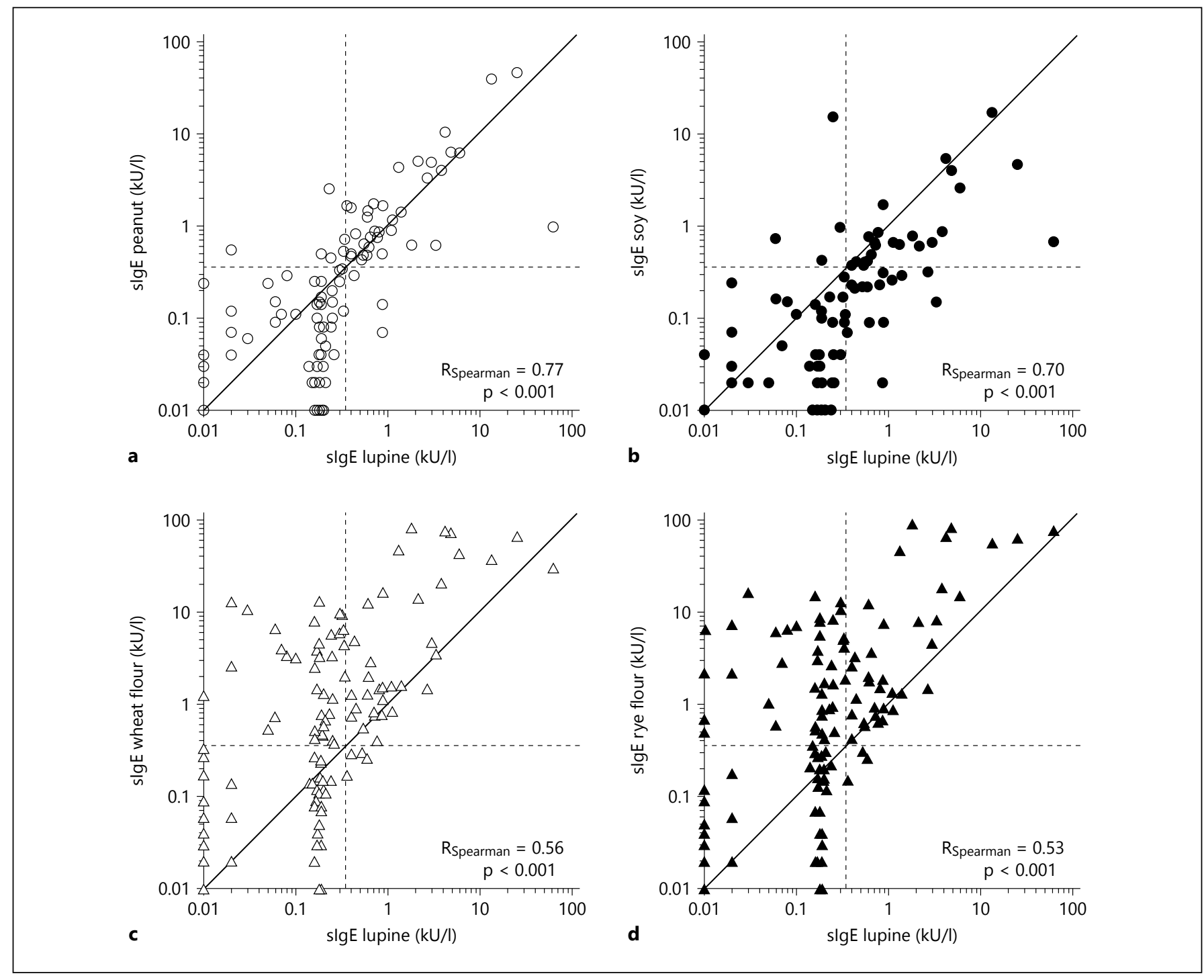

Fig. 2. Correlation between the sIgE concentrations of lupine and peanut (a), soy (b), wheat flour (c) and rye flour (d) in the sera of 116 symptomatic bakers.

$\left(\mathrm{r}_{\text {Spearman }}=0.77\right.$; fig. 2). In general, sIgE values to wheat and rye flour were higher than those to lupine. To clarify whether an overlapping in IgE binding to lupine and wheat/rye flour was due to co-sensitization or cross-reactivity, 8 bakers' sera with moderate-to-high concentrations of lupine sIgE were chosen for inhibition experiments as well as for single allergen testing. With the exception of 1, all bakers were atopic. sIgE to wheat and rye flour as well as to peanut and soy were positive in all bakers, whereas only 2 bakers were positive to rBet $\mathrm{v} 1$. The sera from 3 bakers (No. 5, 6 and 8) reacted to wheat LTP, and the sera from bakers No. 6 and 7 showed IgE binding to both wheat profilin and to HRP (table 1).
IgE binding to lupine was inhibited almost completely (mean inhibition rate: $83 \%$ ) in all 8 bakers' sera using lupine extract as an inhibitor (auto-inhibition; table 2). Using wheat flour as an inhibitor, IgE binding to lupine was also inhibited by $>60 \%$ in the sera from subjects No. $5-8$ (mean inhibition rate in these sera: 78\%). Remarkably, in 3 of the 4 cases the inhibition rate with wheat flour was higher than with lupine itself (table 2). In contrast, inhibition of lupine sIgE by wheat flour was low in sera No. 3 and 4 and negative in sera No. 1 and 2.

To get further information about potential cross-reactive structures and plant panallergens, the 8 sera were tested for their IgE binding profile to CCD, PR-10 pro- 
Table 1. sIgE binding to different ImmunoCAP allergens of 8 selected bakers' sera

\begin{tabular}{|c|c|c|c|c|c|c|c|c|c|c|}
\hline $\begin{array}{l}\text { Subject } \\
\text { No. }\end{array}$ & $\begin{array}{l}\text { Characteristics } \\
\text { (age, nationality, } \\
\text { atopy) }\end{array}$ & $\begin{array}{l}\text { Lupine, } \\
\mathrm{kU} / \mathrm{l}\end{array}$ & $\begin{array}{l}\text { Wheat } \\
\text { flour, kU/l }\end{array}$ & $\begin{array}{l}\text { Rye flour, } \\
\text { kU/l }\end{array}$ & $\begin{array}{l}\text { Peanut, } \\
\mathrm{kU} / \mathrm{l}\end{array}$ & $\begin{array}{l}\text { Soy, } \\
\mathrm{kU} / 1\end{array}$ & $\begin{array}{l}\text { rBet v 1, } \\
\mathrm{kU} / \mathrm{l}\end{array}$ & $\begin{array}{l}\text { Wheat } \\
\text { LTP, } \\
\text { kU/l }\end{array}$ & $\begin{array}{l}\text { Wheat } \\
\text { profilin, } \\
\text { kU/l }\end{array}$ & $\begin{array}{l}\mathrm{HRP}, \\
\mathrm{kU} / \mathrm{l}\end{array}$ \\
\hline 2 & 21 years, DE, a. & 1.81 & 82.60 & 91.50 & 0.62 & 0.78 & 0.12 & 0.05 & 0.04 & 0.14 \\
\hline 3 & 30 years, IT, a. & 4.20 & 77.00 & 66.90 & 10.50 & 5.40 & 0.09 & 0.05 & 0.07 & 5.09 \\
\hline 4 & 40 years, DE, a. & 4.86 & 73.50 & 83.60 & 6.31 & 3.99 & 25.00 & 0.05 & 0.07 & 0.21 \\
\hline 6 & 50 years, ES, a. & 25.10 & 66.50 & 64.00 & 45.80 & 4.64 & 0.15 & 12.50 & 17.70 & 1.04 \\
\hline 7 & 22 years, AT, a. & 13.40 & 37.10 & 56.20 & 39.40 & 17.00 & 0.16 & 0.33 & 18.00 & 61.30 \\
\hline 8 & 27 years, IT, n.-a. & 2.97 & 4.72 & 4.63 & 4.91 & 0.66 & 0.14 & 3.74 & 0.00 & 0.03 \\
\hline
\end{tabular}

Most results were above the threshold of $0.35 \mathrm{kU} / \mathrm{l}$.

IT = Italian; DE = German; ES = Spanish; AT = Austrian; a. = atopic; n.-a. = non-atopic; n.d. = not done.

Table 2. Percentage inhibition rates of ImmunoCAP inhibition experiments in 8 selected bakers' sera

\begin{tabular}{|c|c|c|c|c|c|c|c|c|}
\hline 1 & 92 & 2 & n.d. & n.d. & n.d. & n.d. & n.d. & n.d. \\
\hline 2 & 88 & 16 & n.d. & n.d. & n.d. & n.d. & n.d. & n.d. \\
\hline 3 & 90 & 32 & n.d. & n.d. & n.d. & n.d. & n.d. & n.d. \\
\hline 6 & 58 & 71 & 78 & 1 & 92 & 67 & n.d. & n.d. \\
\hline 7 & 78 & 88 & n.d. & n.d. & 82 & 16 & 95 & 37 \\
\hline 8 & 78 & 87 & 88 & 19 & n.d. & n.d. & n.d. & n.d. \\
\hline \multicolumn{9}{|c|}{$\begin{array}{l}\text { Strong inhibition: }>40 \% \text {; low inhibition: } 20-40 \% . \text { n.d. }=\text { Not done. } \\
{ }^{1} \text { Inhibitor: } 1 \mathrm{mg} / \mathrm{ml} . \\
{ }^{2} \text { Inhibitor: } 0.1 \mathrm{mg} / \mathrm{ml} \text {. } \\
{ }^{3} \text { Inhibitor: } 4.5 \mathrm{mg} / \mathrm{ml} .\end{array}$} \\
\hline
\end{tabular}

tein, profilin, LTP and thaumatin-like protein using ISAC microarrays (table 3). IgE binding to LTP was observed in all 4 sera in which IgE binding to lupine was strongly inhibited by wheat flour (subjects No. 5-8), whereas binding to profilin was seen in only 2 samples. Only 1 serum reacted with the $\mathrm{CCD}$, namely MuXF3.

To confirm the above findings, ImmunoCAP inhibition experiments were performed to assess whether $\operatorname{IgE}$ binding to LTP, profilin or a CCD could be inhibited by lupine. Since the serum from subject No. 7 did not show any IgE binding to the LTP ImmunoCAP, inhibition experiments with LTP were only performed with sera No. 5, 6 and 8 and those with profilin with sera No. 6 and 7. Serum No. 7 was also tested using HRP as an inhibitor.
As shown in table 2, IgE binding to LTP in subject No. 5 was inhibited by lupine in a similar range as by LTP. Also in subject No. 6, the IgE binding to profilin was clearly inhibited by lupine, while only a weak inhibition of IgE binding to HRP by lupine was observed in subject No. 7 .

\section{Discussion}

About one third of 116 European bakers with workrelated allergic symptoms showed sIgE to lupine. In these bakers, sIgE to wheat flour and/or peanut were also positive, and the results indicated a highly significant correlation between sIgE to these allergens. None of the bakers 
Table 3. Positive results of ISAC microarray testing in 8 selected bakers'sera

\begin{tabular}{|c|c|c|c|c|c|}
\hline \multirow{2}{*}{$\begin{array}{l}\text { Subject } \\
\text { No. }\end{array}$} & \multicolumn{5}{|c|}{ ISAC microarray positive } \\
\hline & CCD & PR-10 protein & LTP & profilin & TLP \\
\hline 1 & & $7 / 10^{1,2,3,4,5,6,8}$ & & & \\
\hline \multicolumn{6}{|l|}{2} \\
\hline 3 & & $1 / 10^{2}$ & & & \\
\hline 4 & & $6 / 10^{1,2,3,4,5,6}$ & & & \\
\hline 5 & & & $7 / 8^{1,2,3,4,5,6,7}$ & & \\
\hline 6 & & & $8 / 8^{1,2,3,4,5,6,7,8}$ & $4 / 4^{1,2,3,4}$ & \\
\hline 7 & $1 / 1$ & $1 / 10^{2}$ & $1 / 8^{5}$ & $4 / 4^{1,2,3,4}$ & $1 / 1$ \\
\hline 8 & & & $6 / 8^{1,2,3,4,5,7}$ & & \\
\hline
\end{tabular}

The ratio of positive results to the total number of tested panallergens is shown. Superscripts indicate which panallergens were tested positive. CCD: MuXF3. PR-10 protein: $1=$ rBet v 1 ; $2=$ rAln g $1 ; 3=$ rCor a $1.0101 ; 4=$ rCor a $1.0401 ; 5=$ rMal d $1 ;$ $6=\operatorname{rPrup} 1 ; 7=\operatorname{rGly~} \mathrm{m} 4 ; 8=\operatorname{rArah} 8 ; 9=\operatorname{rAct} d 8 ; 10=$ rApi $\mathrm{g}$ 1. LTP: $1=$ rAra h $9 ; 2=$ rCor a $8 ; 3=$ nJug r $3 ; 4=$ rPru $p 3 ; 5=$ nArt v $3 ; 6=$ nOle e $7 ; 7=$ rPla a $3 ; 8=$ rTri a 14 . Profilin: $1=$ rBet v $2 ; 2=$ rHev b $8 ; 3=$ rMer a $1 ; 4=$ rPhl p 12. TLP: $n$ Act $d 2$.

had reported any food allergy to peanut. In the present study, we show that IgE binding to lupine was inhibited by wheat flour to $>60 \%$ in some cases, results which for the first time support cross-reactivity between lupine and wheat flour.

The bakers in this study were initially examined within the scope of claims for compensation due to occupational asthma in 6 European countries. Because of this selection, the overall prevalence of lupine sensitization in bakers from the different countries could not be estimated. In addition, although we have no information on the actual amount of lupine flour used by the examined bakers, data received from the German bakery industry and from the literature [21] show that lupine flour can be used successfully up to $10 \%$ in bakery products.

According to previous work, sensitization to lupine is frequently not clinically relevant and is most likely caused by cross-sensitization to peanut [1]. None of the bakers in our study had reported peanut allergy, and nearly all lupine-positive bakers showed SIgE to wheat and rye flour. Therefore, it was unclear whether sensitization to lupine flour could be based on cross-reactivity to grain flour, prompting us to perform inhibition experiments. In 4 out of 8 lupine-positive sera, IgE binding to lupine was strongly inhibited by wheat flour, whereas inhibition was low or negative in the other 4 sera (No. 1-4). Interestingly, 2 of the latter sera were positive in ImmunoCAP to rBet $v 1$ and 3 of them to PR-10 proteins in the ISAC microarray. These proteins could be responsible for the cross-reactivity with lupine, peanut and soy in pollensensitized subjects $[1,8]$. In fact, all 4 bakers were atopic, which means that they were SPT positive to either grass pollen, birch pollen and/or house dust mite. Forty-seven percent of all examined bakers were atopic; however, in the lupine-sensitized subjects, this increased to $61 \%$, supporting the results of Gayraud et al. [22], who reported that lupine sensitization is more frequent in subjects with underlying atopy.

The results of the microarray and inhibition experiments with single allergens in the 4 lupine-positive bakers' sera with pronounced wheat inhibition (No. 5-8) suggested that LTP, profilin and/or CCDs seem to be involved in cross-reactivity between lupine and wheat flour. LTPs are known sensitizers via oral exposure, but they can also act as inhalant allergens. The wide distribution of LTPs among plants suggests this panallergen to be responsible for cross-reactivity among fruits and/or pollens $[23,24]$. This cross-reactive potential was supported by the microarray results of subjects No. 5, 6 and 8 who showed IgE binding to at least 6 out of 8 different LTPs. Interestingly, subjects No. 5 and 8 reacted to wheat LTP in the ImmunoCAP but not in the microarray analysis. This phenomenon could be based on the usage of different LTP isoforms [25] or on differences in protein structure after binding to the dissimilar solid phases. However, the relevance of wheat LTP (Tri a 14) as a major allergen involved in baker's asthma was supported by the observation that $60 \%$ of 40 Spanish bakers had sIgE to this protein [26].

Profilins, ubiquitous proteins present in pollen and vegetables, are also panallergens and responsible for the so-called pollen-fruit syndrome due to cross-reactivity. Between 10 and $50 \%$ of pollen-allergic patients are sensitized to profilin, although this is not always clinically relevant [27]. While the sera from the subjects No. 6 and 7 bound to wheat profilin in ImmunoCAP and also to all 4 tested profilins from different plant sources in ISAC, IgE binding to lupine was inhibited by profilin in only 1 serum sample (No. 6). However, the lack of inhibition in serum No. 7 could be based on an insufficient allergen concentration in the inhibitor solution.

It is known that CCDs can be highly cross-reactive and that they are frequently bound by patients who are IgEsensitized to common aeroallergens [28]. Only few data van Kampen/Sander/Quirce/Brüning/ Merget/Raulf 
exist on the prevalence and clinical relevance of IgE binding to CCDs in occupational asthma. Kespohl et al. [29] showed that in a number of wood workers with sIgE to beech or pinewood, IgE binding was clearly reduced by HRP, suggesting that IgE binding was mostly directed to CCDs.

Our findings on the cross-reactivity between wheat flour and lupine due to the recognition of LTP, profilin and CCDs support a previous study that showed $\operatorname{IgE}$ binding to different single wheat flour allergens as well as to HRP and MuXF3 in sera from 40 wheat flour-positive symptomatic bakers and 10 controls with pollinosis [20]. The authors reported that both groups showed IgE binding to profilin and LTP even though the control group had a higher percentage of positive SIgE values than the bakers' group. IgE binding to HRP and MuXF3 was as frequent as to the most relevant recombinant allergens in the bakers' group and nearly as frequent as to the panallergen profilin in the control group. The current results indicate that wheat sensitization of bakers due to inhalative exposure could be primarily responsible for the high prevalence of sIgE to lupine. Also, the high frequency of sensitization to peanut and soy in 92 and $61 \%$, respectively, of lupine-sensitized bakers may be partially based on cross-reactive structures in legumes and cereals because none of these patients reported symptoms to these legumes.

Further plant proteins could play a role in allergenic cross-reactivity in bakers. 1-Cys peroxiredoxin appeared to be a relevant wheat allergen that showed IgE cross-reactivity with seed proteins from barley, rye, rice, maize, soy, oat and spelt. 1-Cys peroxiredoxin was mainly recognized by patients with baker's asthma but not wheat-induced food allergy [30]. As mentioned before, none of the bakers in our study had reported any food allergy. However, there is still the question whether the secondary sensitization of bakers to lupine, peanut and/or soy can cause clinical symptoms after inhalative exposure against these substances. One limitation of our study is the missing data on lupine exposure in bakeries and the fact that in all cases the work-related symptoms of the bakers could be explained by an allergy to wheat and/or rye flour, and therefore no inhalation challenges with lupine flour were performed.

There is little information in the literature about the clinical significance of cross-reactivity between inhalative allergens in occupational settings. As reported by Merget et al. [31], asthmatic subjects without occupational exposure to grain flours, but with a high degree of sensitization to grass pollen allergens and a secondary sensitization to grain flours, showed allergic reactions during challenge tests with wheat/rye flour. On the other hand, a notable finding of a previous study on soy bean-exposed workers was that workers with an increased SIgE or a positive SPT to soy did not have more symptoms than workers with negative tests [32]. The authors concluded that immunological tests for sensitization were not useful in identifying workers with soy bean-related disease.

In conclusion, we could show that lupine sensitization in some of the symptomatic bakers was based on crossreactivity with wheat flour. Moreover, the considerable sensitization rate could also be a sign of an occupational relevance of lupine flour in bakeries. However, lupine exposure levels in bakeries are unknown, and the clinical significance of cross-reactivity with regard to occupational disease remains to be clarified.

\section{Acknowledgements}

This study was supported by the German Social Accident Insurance, project IPA-60-STADOCA, St. Augustin, Germany. We thank the STADOCA group for providing patients' data and sera: N. Kotschy-Lang, H. Müsken, V. Mahler, S. Schliemann, U. Ochmann, J. Sültz, M. Worm, all from Germany; J. Walusiak-Skorupa, Poland; P. Kobierski, Austria; M. Olivieri, Italy; G. Moscato, Italy; J. Sastre, Spain; F. de Blay, France, and I. Folletti, Italy.

\section{References}

1 De Jong NW, van Maaren MS, Vlieg-Boersta BJ, Dubois AEJ, de Groot H, Gerth van Wijk R: Sensitization to lupine flour: is it clinically relevant? Clin Exp Allergy 2010;40:1571-1577.

2 Sheikh SZ, Burks AW: Recent advances in the diagnosis and therapy of peanut allergy. Expert Rev Clin Immunol 2013;9:551-560.

3 Katz Y, Gutierrez-Castrellon P, González MG, Rivas R, Lee BW, Alarcon P: A comprehensive review of sensitization and allergy to soy-based products. Clin Rev Allergy Immunol 2014;46:272-281.

4 Jappe U, Vieths S: Lupine, a source of new as well as hidden food allergens. Mol Nutr Food Res 2010;54:113-126.

5 Moneret-Vautrin DA, Guérin L, Kanny G, Flabbee J, Frémont S, Morisset M: Cross-allergenicity of peanut and lupine: the risk of lupine allergy in patients allergic to peanuts. J Allergy Clin Immunol 1999;104:883-888.
6 Dooper MMBW, Plassen C, Holden L, Lindvik $\mathrm{H}$, Faeste $\mathrm{CK}$ : Immunoglobulin $\mathrm{E}$ crossreactivity between lupine conglutins and peanut allergens in serum of lupine-allergic individuals. J Investig Allergol Clin Immunol 2009; 19:283-291.

7 Sanz ML, de Las Marinas MD, Fernández J Gamboa PM: Lupin allergy: a hidden killer in the home. Clin Exp Allergy 2010;40:14611466. 
8 Guarneri F, Guarneri C, Benvenga S: Identification of potentially cross-reactive peanutlupine proteins by computer-assisted search for amino acid sequence homology. Int Arch Allergy Immunol 2005;138:273-277.

9 Berneder M, Bublin M, Hoffmann-Sommergruber K, Hawranek T, Lang R: Allergen chip diagnosis for soy-allergic patients: Gly $\mathrm{m} 4$ as a marker for severe food-allergic reactions to soy. Int Arch Allergy Immunol 2013;161: 229-233.

10 Hieta N, Hasan T, Mäkinen-Kiljunen S, Lammintausta K: Lupin allergy and lupin sensitization among patients with suspected food allergy. Ann Allergy Asthma Immunol 2009; 103:233-237.

11 Peeters KABM, Koppelman SJ, Penninks AH, Lebens A, Bruijnzeel-Koomen CAFM, Hefle SL, Taylor SL, van Hoffen E, Knulst AC: Clinical relevance of sensitization to lupine in peanut-sensitized adults. Allergy 2009;64:549555.

12 Quaresma RR, Viseu R, Martins LM, Tomaz E, Inácio F: Allergic primary sensitization to lupine seed. Allergy 2007;62: 1473-1474.

13 Wüthrich B: Anaphylactic reaction to lupine flour because of a primary sensitization. Allergy 2008;63:476-477.

14 Parisot L, Aparicio C, Moneret-Vautrin DA, Guerin L: Allergy to lupine flour. Allergy 2001;56:918-919.

15 Crespo JF, Rodríguez J, Vives R, James JM, Reaño M, Daroca P, Burbano C, Muzquiz M: Occupational IgE-mediated allergy after exposure to lupine seed flour. J Allergy Clin Immunol 2001;108:295-297.

16 Campbell CP, Jackson AS, Johnson AR, Thomas PS, Yates DH: Occupational sensitization to lupin in the workplace: occupational asthma, rhinitis, and work-aggravated asthma. J Allergy Clin Immunol 2007;119:11331139.
17 Kogevinas M, Zock J, Jarvis D, Kromhout $\mathrm{H}$, Lillienberg L, Plana E, Radon K, Torén K, Alliksoo A, Benke G, Blanc PD, Dahlman-Hoglund A, D'Errico A, Héry M, Kennedy S, Kunzli N, Leynaert B, Mirabelli MC, Muniozguren N, Norbäck D, Olivieri M, Payo F, Villani S, van Sprundel M, Urrutia I, Wieslander G, Sunyer J, Antó JM: Exposure to substances in the workplace and new-onset asthma: an international prospective population-based study (ECRHS-II). Lancet 2007;370:336-341.

18 Van Kampen V, Merget R, Butz M, Taeger D, Brüning T: Trends in suspected and recognized occupational respiratory diseases in Germany between 1970 and 2005. Am J Ind Med 2008;51:492-502.

19 Van Kampen V, de Blay F, Folletti I, Kobierski P, Moscato G, Olivieri M, Quirce S, Sastre J, Walusiak-Skorupa J, Kotschy-Lang N, Müsken H, Mahler V, Schliemann S, Ochmann U, Sültz J, Worm M, Sander I, Zahradnik E, Brüning T, Merget R, Raulf-Heimsoth M: Evaluation of commercial skin prick test solutions for selected occupational allergens. Allergy 2013;68: 651-658.

20 Sander I, Rozynek P, Rihs H, van Kampen V, Chew FT, Lee WS, Kotschy-Lang N, Merget $\mathrm{R}$, Brüning T, Raulf-Heimsoth M: Multiple wheat flour allergens and cross-reactive carbohydrate determinants bind IgE in baker's asthma. Allergy 2011;66:1208-1215.

21 Ahmed AR: Influence of chemical properties of wheat-lupine flour blends on cake quality. Am J Food Sci Technol 2014;2:67-75.

22 Gayraud J, Mairesse M, Fontaine JF, Thillay A, Leduc V, Rancé F, Parisot L, Moneret-Vautrin DA: The prevalence of sensitization to lupin flour in France and Belgium: a prospective study in 5,366 patients, by the Allergy Vigilance Network. Eur Ann Allergy Clin Immunol 2009;41:17-22.

23 Zuidmeer L, van Ree R: Lipid transfer protein allergy: primary food allergy or pollen/food syndrome in some cases. Curr Opin Allergy Clin Immunol 2007;7:269-273.

24 Larramendi CH, López-Matas MÁ, Ferrer A, Huertas AJ, Pagán JA, Navarro LÁ, GarcíaAbujeta JL, Andreu C, Carnés J: Prevalence of sensitization to Cannabis sativa. Lipid-transfer and thaumatin-like proteins are relevant allergens. Int Arch Allergy Immunol 2013; 162:115-122.
25 Gadermaier G: Non-specific lipid transfer proteins: a protein family in search of an allergenic pattern. Int Arch Allergy Immunol 2014;164:169-170.

26 Palacin A, Quirce S, Armentia A, FernándezNieto M, Pacios LF, Asensio T, Sastre J, DiazPerales A, Salcedo G: Wheat lipid transfer protein is a major allergen associated with baker's asthma. J Allergy Clin Immunol 2007; 120:1132-1138.

27 González-Mancebo E, González-de-Olano D, Trujillo MJ, Santos S, Gandolfo-Cano M, Meléndez A, Juárez R, Morales P, Calso A, Mazuela O, Zapatero A: Prevalence of sensitization to lipid transfer proteins and profilins in a population of 430 patients in the south of Madrid. J Investig Allergol Clin Immunol 2011;21:278-282.

28 Quirce S: IgE antibodies in occupational asthma: are they causative or an associated phenomenon? Curr Opin Allergy Clin Immunol 2014;14:100-105.

29 Kespohl S, Schlünssen V, Jacobsen G, Schaumburg I, Maryska S, Meurer U, Brüning T, Sigsgaard T, Raulf-Heimsoth M: Impact of cross-reactive carbohydrate determinants on wood dust sensitization. Clin Exp Allergy 2010;40:1099-1106.

30 Pahr S, Constantin C, Mari A, Scheiblhofer S, Thalhamer J, Ebner C, Vrtala S, Mittermann I, Valenta R: Molecular characterization of wheat allergens specifically recognized by patients suffering from wheat-induced respiratory allergy. Clin Exp Allergy 2012;42:597-609.

31 Merget R, Sander I, Kampen V, Beckmann U, Heinze E, Raulf-Heimsoth M, Bruening T: Allergic asthma after flour inhalation in subjects without occupational exposure to flours: an experimental pilot study. Int Arch Occup Environ Health 2011;84:753-760.

32 Roodt L, Rees D: Tests for sensitisation in occupational medicine practice - the soy bean example. S Afr Med J 1995;85:522-525. 